\title{
Neil Lazarus, The Postcolonial Unconscious
}

\section{Christine Lorre}

\section{OpenEdition}

1 Journals

Electronic version

URL: https://journals.openedition.org/ces/5975

DOI: 10.4000/ces.5975

ISSN: 2534-6695

\section{Publisher}

SEPC (Société d'études des pays du Commonwealth)

\section{Printed version}

Date of publication: 1 September 2012

Number of pages: 109-110

ISSN: 2270-0633

\section{Electronic reference}

Christine Lorre, "Neil Lazarus, The Postcolonial Unconscious", Commonwealth Essays and Studies

[Online], 35.1 | 2012, Online since 18 April 2021, connection on 23 July 2021. URL: http:// journals.openedition.org/ces/5975 ; DOl: https://doi.org/10.4000/ces.5975

This text was automatically generated on 23 July 2021.

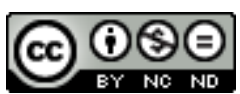

Commonwealth Essays and Studies is licensed under a Licence Creative Commons Attribution - Pas d'Utilisation Commerciale - Pas de Modification 4.0 International. 


\title{
Neil Lazarus, The Postcolonial Unconscious
}

\author{
Christine Lorre
}

\section{REFERENCES}

Neil Lazarus. The Postcolonial Unconscious. Cambridge: Cambridge UP, 2011. x, 299 p. ISBN (pb): 9780521186261. £18,99

1 The "unconscious" in Neil Lazarus's title refers not to Freudian theory, but to a form of social forgetting analysed by Fredric Jameson, notably in The Political Unconscious: Narrative as a Socially Symbolic Act (1981), which Lazarus's own title alludes to, and which involves, for example, the "effacement of the traces of production" of an object (107). Lazarus's point is to call, along with Jameson, for a "return of the repressed" elements of culture, and therefore a reshifting of paradigms in postcolonial criticism.

2 In a long first chapter entitled "The politics of postcolonial modernism," Lazarus starts from a double, related observation: that the corpus of works examined in the field of postcolonial studies is "woefully restricted and attenuated" (22), and that this is due to the often inadequate theory that scholars rely on when developing their analyses of literary works. Here Lazarus is targeting continental theory and the postcolonial theory it inspired in Anglo-American academia that, in Lazarus's terms, gave rise to the "exaltation" of such prevalent concepts as "migrancy, liminality, hybridity, and multiculturality" (21). Drawing on Raymond Williams's writings Lazarus establishes a parallel between modernism and postcolonial criticism to argue that in both cases, a "selective tradition" has been defined and presented as universal while it is actually biased. In response to this situation, Lazarus lists and starts investigating a few major guidelines to develop a new approach to postcolonial literature: "mode of production and class relations," "land and environment," "state and nation," and "structures of feeling." His approach is leftist, and he is unapologetic about the Marxist metaphor of 
base and superstructure or the Williamsian concept of "cultural materialism" that underlie these guidelines.

3 In his third chapter, “'A figure glimpsed in a rear-view mirror': the question of representation in 'postcolonial' fiction," Lazarus starts by observing how, inspired by the pioneering ideas exposed by Edward Said in Orientalism in 1978, postcolonial scholars have produced work analysing "Western" conceptions of the "non-West" that keep feeding the debate over representation in postcolonial studies. Lazarus moves on to comment on the divergences between postcolonial literature and postcolonial criticism, which to him are two forms of discourse that are often at odds, and suggests paying extra attention to three motifs in particular: the critique of "Eurocentric" representation - faced with the looming question of truth in history, how are postcolonial writers to unwrite and rewrite the colonial archive? The critique of "representation itself" (as Eurocentric): the previous consideration has been made increasingly difficult to address as post-structuralist theory challenged concepts of truth and ideology. Finally, the other notion worthy of attention is subalternity, that is to say the need to restore subjectivity to people usually presented as pure victims. Lazarus thus maps out various points at which the theory is not attentive enough to the literature, which calls for a renewed approach.

4 The other three chapters reconsider three major figures that have influenced postcolonial theory. In "Fredric Jameson on 'Third-World Literature': a defence" (chapter 2), Lazarus focuses on two major essays of Jameson's, “Third-World Literature in the Era of Multinational Capitalism" (1986) and "Postmodernism, or, The Cultural Logic of Late Capitalism" (1984). Lazarus argues that Jameson has been mis-read as a postmodernist, while in fact he was focusing on the struggle of colonial societies to become nations; and that, early on, he pointed to the emergence of a new capitalist paradigm that was subsequently analysed as globalisation. Lazarus himself, in his introduction, characterises the emergence of postcolonial studies as a response to globalisation - a response that needs to be reconsidered and criticised. In "Frantz Fanon after the "postcolonial prerogative"' (chapter 4), Lazarus insists on the need to contextualise Fanon's writings, which developed as a reaction against the old (colonial) world order, one that Lazarus considers is not so different from the new world order, making Fanon's work contemporarily relevant. Lastly, "The battle over Edward Said" (chapter 5) challenges the widespread notion that Said's Orientalism was heavily influenced by Michel Foucault's work, a claim that aims at shifting our reading of Said's perspective away from theory and its disavowal of nationalism, towards a more energising form of leftism.

5 The Postcolonial Unconscious reads as a "post-theory" book, one that turns away from abstract, deterritorialised, post-national perspectives, towards a reconsideration of more immediate issues and the way they are rendered in literature. Yet the breadth of the literary works referred to by Lazarus, whether through close reading or through ample lists of further examples, and the scope of the postcolonial world they represent, lead to an enlargement of vision of these issues. It is the role of postcolonial theory to challenge what postcolonial means, and that is what Lazarus does in this book. 


\section{AUTHORS}

\section{CHRISTINE LORRE}

Christine LORRE is a Senior Lecturer in English at the Sorbonne Nouvelle. Her field of research is postcolonial literatures, recent work including publications on the short fiction of Janet Frame and Alice Munro, Asian American and Asian Canadian writers, and postcolonial and globalisation theory. 